\title{
Challenges to Implement Active Learning in Amhara Region Police College, Amhara Regional State, Ethiopia
}

\author{
Kefialew Yenyet (MA) \\ Academics directorate, Amhara Region Police College, Ethiopia \\ Po.box 40, Ethiopia
}

\begin{abstract}
The main purpose of this study was to assess the current practices and challenges of active learning in Amhara Region Police College in teaching police science. To congregate the objective of the study, mixed research design was employed. Simple random sampling for cadets and census method for instructors' was used to select cadets and instructors of Amhara Region Police College. Quantitative data were collected from cadets and instructors using structured and pretested questionnaire. The academic director and research department head were interviewed using interview guide. Data analysis was done in three phases. First, analysis of the quantitative data was done in SPSS Version 24 and percentages, means and a frequency, second, qualitative data was analyzed considering the research question, by using descriptive which is a deductive approach. Finally, quantitative and qualitative results were merged. The findings indicated that almost all instructors and cadets had awareness about active learning. Sometimes instructors are practicing active learning but the level of their practice was not satisfactory. Large class size, lack of administrative support, lack of materials or equipment needed to support active learning and cadets lack of interest on active learning methods were rated as the factors that have been negatively affecting the practice of active learning in Amhara Region Police College. Thus, it is critically important that instructors should be committed to discharge their roles to exercise active learning, the administration of the college and other stakeholders should design and implement a mechanism to monitor the practice of active learning, the concerned bodies of the college should design different mechanisms to avoid these problems by appropriately allocating the time, revising crowded materials and avoiding large and unnecessary contents to practice active learning in Amhara Region Police College.
\end{abstract}

Keywords: Active learning, challenges, Amhara Region Police College, cadets

DOI: $10.7176 / \mathrm{JEP} / 12-1-02$

Publication date: January $31^{\text {st }} 2021$

\section{Introduction}

Education is a universal practice through which students acquire knowledge, develop skill and change in behavior. Realization of goals of any education requires effective teaching and learning process which in turn needs different teaching methodologies to meet the demand of the new generation (ICDR, 1999).

In the era of globalization and technological revolution, education considered as the first step for every human activity. It plays a vital role to develop human capital and linked with an individual's well-being and opportunities for better living (Battle \& Lewis, 2002) cited by (Temesgen, 2016).

Active learning of ideas and skills can occur in a variety of thought-stimulating activities, ranging from direct learning of ideas that explained in a web-page, book, lecture, video, TV or radio show to learning by discovery as in doing an experiment and then trying to discover one's own explanations for what, or in design projects and other kinds of problem solving. These activities can produce active learning, because educationally productive mental activity can occur with or without physical activity in which a variety of mentally active experiences (Craig Rusbult, 2007).

In the Ethiopian context, the new Educational Training Policy of Ethiopia emphasizes to develop problem solving capacity and culture in the context of education, curriculum structure and approach, focusing on the acquisition of scientific knowledge and practicum (MOE, 1994).

The dynamics of policing, strategies have changed time to time. Police executives are requiring their police officers to become problem solvers. These officers must now work with and through the public and community resources in a collective, collaborative approach. This new paradigm has existed for decades and yet the way that police officers are trained has not significantly kept speed with these new requirements (Kooi, 2006).

To effectively implement policing, police departments must make it a priority to educate police officers in the theories and practices of policing and problem-oriented policing, as well as train and encourage officers to translate program elements into actual field activities (Haarr, 2001).

Police officers respond to burglar alarms, enforce traffic laws, arrest different suspects, conduct different crime investigations, perform crime prevention, put out victims through vehicle accident and vehicle fires, put out victims from house fires, answer general questions about how to get somewhere from here, pull and complete many more diverse duties on a daily basis throughout a career. These responsibilities need practical teaching and learning or teaching by doing in the police academy and out of the academy. 
The Education and Training curriculum of ARPC highly encourages a paradigm shift from teacher-centered to student-centered approach. Student-centered approach leads to effective teaching learning and promotes the development of student's critical thinking and to engage them in the teaching learning process actively and effectively. The levels of implementation of active learning practices are different in different institutions. Teachers at all levels of education are expected to implement active learning to attain the desired goal. But researches and experiences have shown that there is a difference between theory and practice in Ethiopian context (Tesfaye, 2015). This is to mean that what has been stated in the policy might not be implemented practically due to some reasons. In relation to this topic, many studies have been conducted in different parts of the country at different levels of the schooling. For example, Different researchers conducted different researches' about the implementation of active learning in primary school and universities.

The researcher has tried to see other related researches done by others. However, most of the researches have been done are based on the implementation of active learning in primary school and universities. For example, Daniel (2014) conducted a research on the implementation of active learning and continuous assessment in Pentecostal theological college and this implies that this work more or less concentrated on continuous assessment. Furthermore, Teshome (2017) also conducted a research on classroom participation and development of student attitudes a study of active learning practices in Ethiopian primary education; he concentrated on classroom participation and development of student attitude on active learning. Moreover, some others also conducted researches on similar issues like Mulatu \& Bezabih (2018) on the effects of teachers' perceptions on the implementations active learning in EFL classroom the case of secondary school.

Generally they found the implementation of active learning was low because of the lack of budget, large class size, due to the perception of teachers about active learning, lack of training are the factors that hinder the implementation of active learning (Daniel, 2014), (Teshome, 2017), (Mebratu, Mulatu \& Woldemariam, 2018), ), (Biruh, 2018).

However the above researchers conducted their research based on selected elementary school, secondary school and civil universities. What sets this study apart from other studies is the fact that the police college learning process is different from the above educational institution. So, the law enforcement professions need unique teaching and learning environment with different learning approach from the above educational institution. Therefore, all these researches do have relations one another since they share something in common i.e. they all are studies on the implementation of active learning.

With this regard, the researcher believed that he had to search other more related research done by others because all the researches mentioned above are the implementation of active learning. Even if they are the practices and implementation of active learning and they share the same thing with this research. But the current research relies especially on practices of active learning in ARPC. Therefore, Biruh (2018) conducted a research on an assessment of practice of active learning approach in Wolita Sodo University Health Science College. However, his research has covered only the universities specially Health Science Colleges. It did not include police academy and doesn't cover the challenges to implement active learning in police academy. As it is known police officers and health professionals do have quite different works in the task areas. Taking this fact in to account, this study was aimed at assessing the current practice of active learning in police academy.

\subsection{Research question of the study}

This study will answer the following basic questions.

1. To what extent active learning is implementing in Amhara Police College?

2. What are the challenges that affect the implementation of active learning?

\subsection{Objectives of the study}

The general objective of this study was to assess the current practices of active learning in Amhara Region Police College. Specific objectives are;

$>\quad$ To identify the current practices of active learning in Amhara Region police college.

$>$ To identify the challenges that hinders the implementation of active learning in Amhara Region Police College.

\section{Research Methodology}

This study was conducted by using the mixed method approach. Because this method helps the researcher to see the issue under study both from qualitative and quantitative perspective.

Descriptive survey research design was used for this study. It was selected for the reason that enables the researcher to get current information about the current practice of active learning in ARPC. It is also relevant to collect detailed and a variety of information about practice of active learning. 


\subsection{Population \& Sampling method}

In ARPC there is 31 instructors, one general director and three vice directors, $125,3^{\text {rd }}$ round regular diploma cadets. The target population that is represented in the study is Amhara Region Police College. The participants of the study were academics directors, research department heads, instructors, and $3^{\text {rd }}$ round cadets of ARPC. The researcher limited the number of participants to a more manageable number of people. 128 people were participated during the time of the study. The numbers of academics director and research department heads were 2 , the numbers of participating instructors were 31 and the numbers of cadets' sample were 95.

\subsection{Data collection instruments.}

\subsection{Method of data analysis}

Data analysis was done in three phases. In the first phase the quantitative data was analyzed using a quantitative approach. The collected data analysis was done in SPSS Version 24. Frequencies, percentages and means were used during the data analysis.

In the second phase the qualitative data was analyzed considering the research question, using framework coding which is a deductive approach. Frequencies, percentages, mean and descriptive statements were used to give answers for research questions. The response categories in Likert scales have a rank order.

After analysis of the quantitative and qualitative data separately, results were merged and there was a common interpretation phase to look for answers to the research questions and to yield insights for the discussion and conclusion of this study.

\subsection{Discussion of Results}

In this study, an attempt is made to explain the results of the study with reference to the basic questions formulated understatement of the problem. The major ideas or theme of the discussion questions are:

1. To what extent active learning is implementing in Amhara Police College?

2. What are the challenges that affect the implementation of active learning?

\subsubsection{Amhara Region Police College instructors and cadets practices of active-learning}

In this research finding, the study revealed that most instructors and cadets mostly have a positive perception towards active learning method. But their positive perception doesn't let them to practice active learning in ARPC. In addition to questionnaire and interviews, the researcher confirmed that the process of active learning method at ARPC is at a low level, as observed in class room. Based on the analysis of quantitative and the qualitative data, we can say that the level of implementation of active learning strategies in ARPC was low.

\subsubsection{Challenges that affect the implementation of active learning in Amhara Region Police College}

In the time of teaching-learning process, active learning too may face different factors during its implementation in the real classroom conditions. The researcher has selected seven possible factors affecting the implementation of active learning in ARPC.

Shortage of time, lack of skill to practice different teaching techniques due to lack of pre service trainings and inadequacy of in-service trainings on teaching methodologies, student lack of interest on active learning method, shortage of necessary resources, lack of enough administrative support, large number of students in classroom were the factor that hinder to practice active learning in ARPC.

Generally different researcher and author found that the practices of active learning in educational institution were low because of the lack of budget, large class size, due to the perception of teachers about active learning, lack of training are the factors that hinder the implementation of active learning (Daniel, 2014), (Teshome, 2017), (Mulatu \& Bezabih, 2018), (Biruh, 2018). In this study the researcher confirmed that those factors that are listed by authors and researchers are factors that hinder the practices of active learning in ARPC.

\subsection{Conclusions}

Even though there are few practices of active learning in Amhara Police College, the practice of active learning in the college was not founded satisfactory.

Regarding to the factors that affects the implementation of active learning in Amhara Region Police College, large class size, lack of administrative support, lack of materials or equipment are needed to support active learning and students lack of interest on active learning methods were rated as the factors that have been negatively affecting the utilization of active learning strategies in ARPC. With regard to instructors and cadets understanding of active learning, the findings showed that almost all the instructors and cadets have perceived active learning positively but they didn't practice it.

\subsection{Recommendations}

Based on the conclusions drawn above, the following recommendations were advanced to improve the implementation of active learning.

- The level of use of active learning can be enhanced if the instructors are able to provide the circumstances 
that encourage active participation of students in the teaching learning process regularly.

- The administration of the college and other stakeholders should design and implement a mechanism to monitor the practice of active learning regularly.

- The result of this study identified that shortage of time were the factors which hindered the practice of active learning. So, the concerned bodies of the college should design different mechanisms to avoid these problems by appropriately allocating the time, revising crowded materials and avoiding large and unnecessary contents.

- Instructors and cadets tendency towards traditional lecture method was also another problem in the college. To avoid this problem, the college should prepare different trainings, seminars and courses to bring attitudinal change on the minds of instructors and cadets of the college.

\section{List of reference}

Alston, M., \& Bowles, W. (2018). Research for social workers: An introduction to methods. Aotearoa New Zealand Social Work, 30(3), 96. Https://doi.org/10.11157/anzswj-vol30iss3id549

Amare, A. (1999). Availability and Use of Instructional Materials in Tigray Primary Schools. 7(1), 53-66.

Amhara Region Police College. (2015). Regular Diploma Curriculum in Police Science.

Augustine, F. L., Bozylinsky, J. M., Folley, V. L., Lynch, P. P., O’Keefe, J. A., Lentini, J. R., Pantaleoni, C. A., Riddle, D. H., Schildecker, C. B., Schonfeid, N. R., Stinchcomb, J. D., Styles, J. C., \& Velzy, R. J. (1976). LAW ENFORCEMENT TECHNOLOGY. U.S. Government Printing Office. Https://doi.org/017-080-01402

Belihu, G. A. (2010). Tension between traditional and modern teaching-learning approaches in Ethiopian primary schools. Proceedings of World Conference on Educational Multimedia, Hypermedia and Telecommunications 2010, 9(1), 2617-2628.

Best, J.W. and Kahn, J. (1997). Research in Education (7th ed.).

Birhanu, M. (2010). Active learning approaches in mathematics education at universities in Oromia, Ethiopia (Issue November). UNIVERSITY OF SOUTH AFRICA.

Biruh, A. (2018). An Assessment of Practice of Active Learning Approach in Wolita Sodo University Health Science College, Southern Ethiopia: The Case of Preclinical Classes.

Bixley, B., \& Yamane, T. (1965). Statistics: An Introductory Analysis. The Canadian Journal of Economics and Political Science, 31(1), 163. Https://doi.org/10.2307/139661

Bonwell, C., \& Eison, J. (1991). Active learning : creating excitement in the classroom /. School of Education and Human Development, George Washington University.

Borich, G. D. (1984). Effective Teaching Methods. Macmillan Publishing Company.

Brewerton, P., \& Millward, L. (2001). Organizational Research Methods. SAGE Publications.

Caffarella, R., \& Merriam, S. (1999). Learning in adulthood: A comprehensive guide. San Francisco: Jossey-Bass.

Capel et. Al. (1995). Learning to Teach in the secondary Schools. London: Rutledge.

Charles, C., \& James, A. (1991). Active learning Creating Excitement in the Classroom.

Chervase, C. (2016). Active methods for language learning. "Alexandru Ioan Cuza” Police Academy, Bucharest, RomaniaCchervase@yahoo.Co.UkABSTRACT,2(2).

Daniel, Y. (2014). The Implementation of Active Learning and Continuous Assessment in Pentecostal Theological College. June.

Dary, N. And Terry, E. (1993). Reforming Open and Distance Education: Critical Reflection Practice. London: Kogan Page.

Debela, W. (2017). Implementation of student-centered approach in teaching physicaleducation class room. The case of some selected high schools in Lalo Assabi Woreda,West Wollega Zone, Western Ethiopia (Issue March). Haramaya University, Ethiopia.

Dekanoidze, K., \& Khelashvili, M. (2018). Police education and training systems in the OSCE region. Https://www.osce.org/files/f/documents/f/7/423401.pdf

Desalegn, G. (2014). The implementation of active learning approach in teaching algebra in secondary schools of East Wollega Zone, Oromia Regional State. Addis Ababa University.

Desta, A. (2001). Factors Influencing The Implementation of Problem Solving Approach In The Second Cycle Primary Schools of Tigray (Issue June). Addis Ababa University.

Déverge, C. A. (2016). Police Education and Training : A Comparative Analysis of Law Enforcement Preparation in the United States and Canada.

E. Dale. (1969). Dale's Cone of Experience.

Eggen, P. ., \& Kauchax, D. P. (1996). Strategies for Teachers: Teaching Content and Thinking Skills. Boston: Allyn and Bacon.

Fink, L. D. (2003). A Self-Directed Guide to Designing Courses for Significant Learning. San Francisco: JosseyBass.

Frazee, \& Al, M. B. Et. (1995). Integrated Teaching Methods: Theory Classroom Approach., and field based 
Connections (New York:).

Fritsvold, E. (2020). Going Beyond the Bachelor's: Why Police Officer Education is So Important. University of San Diego. Https://onlinedegrees.sandiego.edu/why-police-officer-education-is-important/

Gara, L., \& Asrat, D. (2014). Attitude of teachers towards the use of active learning methods.

Gupta, N. K., Banerjee, K., Uppal, S., Ganguly, G., John, M., \& Srivastava, S. (2014). Basics in Education. Http://www.ncert.nic.in/pdf_files/basic_in_education.pdf

Haarr, R. N. (2001). T he $m$ aking of a c ommunity $p$ olicing o fficer : $t$ he $i$ mpact of $b$ asic $t$ raining and $o$ ccupational s ocialization. 4(4).

ICDR. (1999). Teacher Education Hand Book. Adiss Abba Finfine Printing and Publishing.

John, P. (2012). Meaning, Nature and Aims of Education.

Kirpik, C. (2012). Active learning in history and social studies.

Kooi, G. P. Vander. (2006). Problem-Based Learning : an Attitudinal Study of Police Academy Students.

Kothari, C. R. (2004). Research methodology: methods and techniques. In New Age International (2nd ed.).

Https://doi.org/http://196.29.172.66:8080/jspui/bitstream/123456789/2574/1/Research\%20Methodology.pdf

Kumar, S., \& Sajjad Ahmad. (2008). True meaning of education. In MEANING, AIMS AND PROCESS OF EDUCATION (pp. 1-92). University of Delhi. Https://doi.org/110007

Kyriacou, C. (2007). Essential teaching skills. In Bmj (3rd ed., Vol. 335, Issue Suppl S4). Nelson Thornes Ltd. Https://doi.org/10.1136/sbmj.0710361

Latefy, S. (2016). THEORETICAL FOUNDATIONS OF ACTIVE LEARNING.

Macharia, S. N., \& Waria. (1994). Teaching Practice in Primary Schools. Hong Kong:Macmillan Publishing Company.

Mcleod, G. (2001). Learning Theory and Instructional Design. 35-43.

Mebratu, Mulatu \& Woldemariam, B. (2018). The Effects of Teachers' Perceptions on the Implementations Active Learning in EFL Classroom: The Case of Three Selected Secondary Schools in Dawro Zone, SNNPRS, Ethiopia. 18(6).

Michael, P. (2004). Does Active Learning Work? A Review of the Research. In Department of Chemical Engineering Bucknell University (Vol. 93, Issue July).

Morgan, J., Barroso, L. R., \& Simpson, N. (2014). Active Demonstrations for Enhancing Learning. June. Https://doi.org/10.1109/FIE.2007.4418057

Mulatu \& Mebratu. (2018). Perceptions and Practices of EFL Teachers in Implementing Active Learning in English Classes : The Case of Three Selected Secondary Schools in Dawro Zone, Snnprs , Ethiopia. Journal of Literature, Languages and Linguistics, 41, 26-33.

Nurma, W. (2017). Active learning models using techniques learning start with a question to increase liveliness of students in accounting learning class xi accounting 1 smk negeri 1 yogyakarta academic year 2016/2017.

Orey, M. (2014). Emerging Perspectives on Learning,Teaching, and Technology. In M. Drexel (Ed.), Primary Teaching Assistants: Curriculum in Context. The Global Text Project is funded by the Jacobs Foundation. Https://doi.org/10.4324/9780203422090

Ormrod, J. E. (2012). Human learning (Lauren Carlson (ed.); 6th ed.). Pearson Education, Inc.

Ornstein, A., \& Hunkins, F. (2009). Curriculum Design. In Curriculum: Foundations, Principles and Issues. 5th $E d, 181-206$.

Peggy, M. (2016). Active Learning. In Active Learning Definitions and Toolkit of Online Resources Prepared for the UNMC College of Medicine Curriculum Leadership (pp. 1-2).

Pual, B., Harrrison, C., Lee, C., Marshall, B., \& Wiliam, D. (2005). Putting it into practice Assessment for Learning Putting it into practice ( 7 th ed.). Open university press.

Ramsden, P. (1993). Learning to Teach in Higher Education. In Studies in Higher Education (Vol. 18, Issue 1). Https://doi.org/10.1080/03075079312331382498

Rudolph, A. R., \& Orwin, C. (2005). Active . Learning. 3, 1-7.

Ryan, C. M. (2008). Pedagogy, police training, D/discourses - subcultures and situated identities and meanings. $1-13$.

Sasikumar, N. (2018). Impact of active learning strategies to enhance student. Innoovare Journal of Education, December.

Saunders, M., Lewis, P., \& Thornhill, A. (2009). Research Methods for Business Students (5th ed.).

Shipton, B. (2009a). J ournal of Learning Design. 3(1), 57-67.

Shipton, B. (2009b). Problem Based Learning: Does it provide appropriate levels of guidance and flexibility for use in police recruit education? Journal of Learning Design, 3(1), 57-67.

Silberman, M. (1996). Introduction to active learning. Active Learning: 101 Strategies to Teach Any Subject, 121.

Tavares-dos-Santos, J. V. (n.d.). Police Education an approach frem Brazil.

Taye Geressu. (2008). Perceptions and practices of active learning in EFL classes of Dilla University. In 
Department of Biotechnology - College of Science - University of Baghdad. Baghdad, Iraq: Vol. Volume 49 (Issue Ethnic Journal of Science) (Vol. Vol49, Issue The Ethnic Journal of Science).

Tesfaye, S. (2015). Improving Students 'Participation in Active Learning Methods: Group Discussions , Presentations And Demonstrations: A Case of Madda Walabu University Second Year Tourism Management Students of 2014. 6(22), 29-33.

Teshome, N. (2017). Classroom Participation and Development of Student Attitudes : A Study of Active Learning Practices in Ethiopian Primary Education. International Journal of Humanities Social Sciences and Education (IJHSSE), 4(3), 67-85.

Tricia, W. (2019). 9 benefits of active learning.

Vodde, R. F., \& Robert, F. (2009). Andragogical Instruction for Effective Police Training Andragogical Instruction for Effective Police Training. 716, 19-20.

Weimer, M. (2012). Principles of Active Learning.

Weisburd, D., \& Neyroud, P. (2011). New Perspectives in Policing Police Science: Toward a New Paradigm. National Institute of Justice.

Yin, X., Zhang, J., \& Wang, X. (2004). Sequential injection analysis system for the determination of arsenic by hydride generation atomic absorption spectrometry. Fenxi Huaxue, 32(10), 1365-1367. Https://doi.org/10.1017/CBO9781107415324.004 